2. Signed this Seventeenth Day of November of the year One Thousand Nine Hundred and Eighty-Six at Bangalore, India.

\title{
ASEAN DECLARATION ON THE SOUTH CHINA SEA*
}

\section{Manila, 22 July 1992}

We, the Foreign Ministers of the member countries of the Association of South East Asian Nations,

Recalling the historic, cultural and social ties that bind our peoples as States adjacent to the South China Sea,

Wishing to promote the spirit of kinship, friendship and harmony among our peoples who share similar Asian traditions and heritage,

Desirous of further promoting conditions essential to greater economic cooperation and growth,

Recognizing that we are bound by similar ideals of mutual respect, freedom, sovereignty and mutuality of interests,

Recognizing that South China Sea issues involve sensitive questions of sovereignty and jurisdiction of the parties directly concerned,

Conscious that any adverse developments in the South China Sea directly affect peace and stability in the region,

Hereby

1. Emphasize the necessity to resolve all sovereignty and jurisdictional issues pertaining to the South China Sea by peaceful means, without resort to force;

2. Urge all parties concerned to exercise restraint with the view to creating a positive climate for the eventual resolution of all disputes;

3. Resolve, without prejudicing the sovereignty and jurisdiction of countries having direct interests in the area, to explore the possibility of cooperation in the South China Sea relating to the safety of maritime navigation and communication, protection against pollution of the marine environment, coordination of search and rescue operations, efforts towards combatting piracy and armed robbery as well as collaboration in the campaign against illicit trafficking in drugs;

4. Commend all parties concerned to apply the principles contained in the Treaty of Amity and Cooperation in South East Asia as the basis for establishing a code of international conduct over the South China Sea;

5. Invite all parties concerned to subscribe to this Declaration of Principles.

Signed in Manila, Philippines, this 22nd day of July, nineteen hundred and ninetytwo.

* Courtesy of Dr. KriangSAK Kittichaisaree, Bangkok 